\title{
VISUAL OPERASI MENGHAPUS SERANGAN LANUN DI NUSANTARA DARI LAPORAN THE ILLUSTRATED LONDON NEWS, 1845-1872
}

\author{
Azian Tahir \\ Arba'iyah Mohd Noor
}

\begin{abstract}
The Malay Archipelago in Southeast Asia comprising islands rich in natural resources was the main reason for its significance in the commercial trade lane via sea routes in Asia. These bustling sea activities led to attacks on ships and seizures of goods by pirates. Various measures were carried out by the colonial outhorities against the pirates in the hope of destroying them and reviving the thriving commercial activities. In order to protect the political and economic interests of the ruling party/government then, the gruesome activities of the pirates had to be reported to all parties. Such As, The Illustrated London News (ILN) took several initiatives to report on the development and steps taken to battle pirate attacks and activities of the British in their colonies, especially in Southeast Asia. Each report was enclosed with visual prints related to the incidents. These include efforts to eliminate the pirates in the Borneo Island, especially in Sabah and Sarawak and also the Sulu archipelago.
\end{abstract}

\section{Pengenalan}

Perdagangan menggunakan jalan laut bermula sejak manusia memulakan kehidupan perekonomian iaitu bertukar-tukar barangan untuk keperluan mereka. Seiring dengan itu, kegiatan lanun juga telah 
berkembang pesat dan mendatangkan masalah kepada para pedagang. Terdapat banyak dokumentasi bertulis yang boleh diperoleh mengenai serangan lanun terhadap kapal dagangan. Namun dokumentasi berkenaan serangan lanun menggunakan cetakan amat kurang ditonjolkan di rantau ini. Visual berkaitan lanun seringkali ditemui dari satu peradaban ke satu peradaban yang maju mengikut zamannya. Ia ditemukan dalam bentuk gurisan batu, lukisan dinding di makammakam kerajaan lama dan akhir sekali dalam bentuk cetakan atas kertas. Kegerunan dan keganasan yang dilakukan oleh mereka didokumenkan dengan tujuan untuk merekod bagaimana lanun ini telah memusnahkan banyak peradaban lama terutama yang dibina di persisiran pantai.

Di rantau Alam Melayu terutama di perairan pelayaran laut antara China dan India juga tidak terkecuali daripada ancaman lanun. Malahan dikatakan serangan lanun di Semenanjung dan Borneo merupakan antara serangan lanun yang paling digeruni. Lanun selalunya menyerang untuk merompak barangan berharga dan menjadi kaya melaluinya. Pihak British yang menjajah Tanah Melayu dan Borneo terpaksa berdepan dengan berbagai serangan lanun, terutama di kawasan-kawasan pelabuhan dan tempat pengambilan bahan mentah yang berkepentingan. Oleh itu, mereka akhirnya akur akan keperluan untuk menghapuskan serangan tersebut terutama sekali apabila para pedagang, pelayar, pengembara dan pelancong kian kerap menjadi mangsa lanun.

Beberapa tindakan dibuat untuk menghapuskan lanun dan penempatan mereka terutamanya di kepulauan Borneo dan pulau-pulau berhampiran dengannya. Menerusi tindakan itu, beberapa laporan berkaitan usaha tersebut telah diterbitkan dalam bentuk laporan berita di akhbar bervisual pertama dunia. Laporan yang lengkap dengan visual cetakan daripada teknik gurisan kayu ini mempunyai edaran di seluruh dunia terutama sekali di negara-negara jajahan British. Akhbar The Illustrated London News (ILN) dicetak dan diterbitkan di London secara tidak langsung telah menjadi lidah rasmi untuk melaporkan setiap tindakan yang telah dan berjaya dijalankan oleh pihak British dalam usaha menghapuskan kumpulan lanun.

\section{Lanun di Nusantara dan Siapa Mereka?}

Perkataan 'Pirate' yang biasa digunakan ini membawa maksud 'Lanun' dalam bahasa Melayu. Perkataan tersebut berasal daripada bahasa Inggeris yang merujuk kepada istilah Yunani bermaksud percubaan, serangan atau ceroboh. ${ }^{1}$ Menurut Dewan Bahasa dan Pustaka, 'Lanun' merupakan orang yang melakukan rompakan atau rampasan dengan kekerasan dan kekejaman di kawasan laut sama ada laut 
dalam atau persisiran pantai. ${ }^{2}$ Namun, menurut pendapat Benerson Little, terma 'Pirate' seringkali dilihat seolah-olah tidak mencukupi dengan melibatkan gambaran hanya pada mereka yang mencuri di laut. Terdapat pelbagai lagi jolokan dengan terma yang lain biasanya ditambah untuk memberi gambaran terhadap lanun ini. ${ }^{3}$ Walaupun terdapat beberapa terma yang diperkatakan namun secara harfiah jelas setiap apa yang membabitkan aktiviti melawan pihak berkuasa ketika di laut atau pesisiran pantainya merupakan satu kegiatan lanun.

Terdapat banyak rekod berkenaan aktiviti lanun yang telah berlaku di negara-negara kaya yang mempunyai pelabuhan dan bahan mentah. Tanah Melayu dan Boneo yang dikelilingi dengan laut iaitu Selat Melaka, Laut Cina Selatan dan Laut Sulu sudah pasti mempunyai sejarahnya tersendiri. Donald B. Freeman menyatakan bahawa rujukan awal berkaitan lanun di kawasan Selat Melaka adalah daripada risalah abad ke-14 oleh penulis China, Lung-Ye Men. Beliau menyatakan tempat yang diwartakan sebagai kawasan lazim serangan lanun ialah di Selat Gigi Naga (Dragon-Teeth Straits) yang terletak di Selat Teberau antara pantai Selatan Singapura dan Belakang Mati. ${ }^{4}$

Selain itu, terdapat beberapa kawasan lain yang juga telah direkodkan oleh pihak Barat sebagai kawasan serangan lanun iaitu di sepanjang bahagian tertentu di Selat Melaka. Tempat-tempat itu terkenal pada satu-satu masa sebagai tempat persembunyian dan serangan hendap lanun. Lazimnya tempat tersebut dibahagikan kepada kedudukan mengikut bangsa. Contohnya, lanun yang berbangsa Melayu tempatnya di Sungai Perai bertentangan Pulau Pinang, Sungai Larut, Pangkor dan Dinding serta pesisiran pantai di Selangor dan Singapura. ${ }^{5}$ Kawasan pantai barat Tanah Melayu ketika itu merupakan tempat yang berbahaya. Menurut Simon Richmond, Pangkor pernah menjadi tempat persembunyian lanun dan memainkan peranan dalam pertempuran untuk mengawal Selat Melaka. ${ }^{6}$

Lanun kebiasaannya dikaitkan sebagai orang terbuang, penjenayah, tidak mempunyai darjat. Malahan terdapat juga di antara mereka yang terdiri daripada anggota tentera laut yang tidak mengemari tugasan mereka kerana terikat dengan undang-undang yang ketat. Terdapat di antara mereka cara kehidupan yang bebas dan mengembara. Apabila kesemua mereka ini bertemu sesama sendiri dalam satu kumpulan yang besar, akhirnya membentuk satu kumpulan anak kapal dan pelayar yang bergelar 'Lanun'. ${ }^{7}$ Melalui pelbagai laporan yang telah dibuat berkaitan lanun, mereka kebanyakannya berasal dari Semenanjung Tanah Melayu, Dayak Laut di Sarawak (Borneo Barat), pelayar dari Mindano di Selatan Filipina dan juga pelayar dari Kepulauan Sulu dari Barat Daya Filipina. Dilaporkan, terdapat lanun daripada bangsa Bugis, 
Cina, Thai dan juga berbangsa Eropah. Kesemuanya terkenal sebagai pemburu hamba dan bergerak secara aktif pada abad ke-19. ${ }^{8}$

Mereka membunuh dan menyerang dalam usaha menawan sesebuah kapal yang disyaki membawa emas, perak dan barangan berharga lain. Modus operandi mereka ialah membunuh dan mencederakan semua anak kapal serta penumpang sekiranya kehendak mereka tidak dituruti. Serangan lanun yang berlaku berkait rapat dengan hubungan ekonomi, politik dan kedudukan geografi itu sendiri. Selain itu, mereka juga amat terkenal kerana keberanian. Dalam satu kes, 'Raga' yang merupakan seorang ketua lanun berasa amat terkejut apabila pihak British menghantar dua buah kapal perang untuk menyerangnya pada awal abad ke-19.

Merujuk kepada Dayak Laut pula, ianya dikenali secara rasmi sebagai pahlawan dan pemburu kepala serta sering bersekutu dengan pelayar atau lanun Melayu. Pelayar atau lanun Sulu pula merupakan lanun dan pemburu hamba yang mahir dengan armada laut yang besar dan selalunya mereka menyerang ketika Monsun Barat Daya. Oleh itu, mereka lebih dikenali oleh orang tempatan sebagai "Lanun Angin." Mereka inilah yang hebat menentang dan ditentang oleh Sepanyol, Belanda dan British. Pada abad ke-19, British mula menyerang balas kawasan Lanun Sulu seperti di sekitar laut sekeliling Austronesia berhampiran kawasan penduduk Polynesia. ${ }^{9}$ Dalam pemburuan lanun di Borneo, pihak British telah berusaha untuk menghapuskan ancaman lanun untuk menjaga kepentingan perdagangan mereka.

\section{Kepentingan British dan Polisi Memerangai Lanun}

Pada dasarnya British tidak mahu campurtangan dalam urusan negeri di rantau Asia Tenggara selain tanah jajahan yang sedia ada. Namun atas desakan dan keyakinan ekonomi, kerajaan British telah meluluskan 'Piagam Pentadbiran-Pantauan Komersial Utara Borneo' pada Disember $1881 .{ }^{10}$ Kedudukan perdagangan antara China dan India secara langsung memberikan perhatian kepada British dalam usaha menjaga kepentingan di Borneo. Pada pertengahan abad ke19, kepentingan utama British di Asia Tenggara bukan sahaja dalam pemerintahan atau penaklukan tanah jajahan, tetapi turut mengambil berat terhadap kawasan perairan laluan perkapalan komersial antara India dan China (dan dari India ke England dan seluruh Eropah). ${ }^{11}$ Di sebalik itu, British juga memerlukan penempatan di Borneo untuk mendapatkan bekalan arang batu dengan mudah dari Brunei. Arang batu ketika itu amat penting kerana merupakan bahan bakar utama dalam industri perdagangan dan perkapalan melalui teknologi kapal berenjin wap. ${ }^{12}$ 
Campurtangan British ke atas Borneo Utara yang kini dikenali sebagai Sabah bermula pada tahun 1881 oleh 'British North Borneo Company'. Campurtangan tersebut sebenarnya merupakan perjanjian yang diambil alih daripada perjanjian asal yang dibuat oleh 'American Adventurer' pada tahun 1865. ${ }^{13}$ 'British North Borneo Company' yang kemudiannya dikenali sebagai 'Chartered Company' diberikan tanggungjawab untuk menguruskan semua wilayah jajahan British melalui seorang wakil British yang bernama, Alfred Dent. Beliau bukan sahaja telah berjaya mendapatkan pertukaran hak milik melalui perkenan daripada Sultan Brunei, malah turut diperkenankan oleh Kesultanan Sulu. ${ }^{14}$

Labuan pula menjadi kepunyaan British pada 1846 dan dijadikan pengkalan tentera laut melalui perjanjian di antara British dan Sultan Brunei. ${ }^{15}$ Pada peringkat awal pentadbiran, Labuan merupakan sebahagian daripada Singapura sehingga tahun 1912 kemudian dipisahkan apabila Singapura menjadi sebahagian daripada Negeri Selat. ${ }^{16}$ Sarawak pula diperoleh daripada Sultan Brunei lebih awal iaitu pada tahun 1842 oleh James Brooks. Namun pada 1888, Sarawak telah diserahkan oleh kerajaan British kepada James Brooks yang dikenali sebagai 'White Rajah' yang bermaksud Raja kulit putih. Beliau diberi perlindungan oleh pihak British dan sentiasa mendapat sokongan British dalam apa sahaja urusan di Sarawak. ${ }^{17}$

\section{Akhbar The Illustrated London News}

The Illustrated London News (ILN) ditubuhkan pada 1842 oleh gabungan dua orang penting dalam industri akhbar ketika itu iaitu Henry Ingram dan Henry Vizetelly. Henry Ingram merupakan pemegang modal yang terbesar manakala Henry Vizetelly pula ialah seorang pencetak. ILN mula diterbitkan pada 14 Mei 1842 dan mendapat sambutan yang baik daripada pembaca walaupun pada asalnya hanya disertai dengan visual gurisan kayu yang kecil di halaman muka hadapannya. ${ }^{18}$ Pengarang mencatatkan di halaman muka hadapan terbitan pertama ayat ini: 'the public will have henceforth under their glance, and within their grasp, the vary form and presence of events as they transpire ${ }^{19}$ yang bermaksud orang ramai akan berupaya memberi maklumat atau berita di hadapan dan di dalam genggaman mereka seolah-olah dalam bentuk peristiwa itu berlaku secara langsung. Ia memberi gambaran bahawa sebarang bentuk berita dan keadaan terkini yang dilaporkan seolah-oleh dialami oleh pembaca di mana dan bagaimana ianya berlaku.

ILN merupakan syarikat akhbar pertama yang mempelopori penggunaan 'Gurisan Kayu' sebagai teknik cetakan pada penerbitan akhbar. ${ }^{20}$ Pengarang pertamanya ialah F.W.N. Barley, namun 
orang sebenar yang memainkan peranan utama dalam memaju dan menggerakkan akhbar mingguan bergambar ini ialah John Timbs. Beliaulah yang sebenarnya mengerakkan akhbar ini dengan mengumpulkan tenaga pencetak yang terdiri daripada golongan pengkarya seni cetak yang berbakat. Mereka ini merupakan kunci utama dalam penghasilan akbar bervisual tersebut. Kehadiran akhbar ini dalam dunia penerbitan telah menempuh era baru dengan jayanya dan pengedarannya meliputi seluruh dunia sehingga mencecah 300,000 salinan berbanding akhbar biasa yang hanya mampu menjual 70,000 salinan sahaja. ${ }^{21}$ Walaupun pada peringkat awal para pengkarya/ pencetak yang berkhidmat di akhbar ini tidak dihargai penglibatan mereka (biasanya tanpa nama), namun penglibatan dan peranan mereka penting dalam penghasilan prototaip ilustrasi akhbar tersebut. ${ }^{22}$

'The Illustated London News' (ILN) diperkenalkan kepada umum atas kesedaran bahawa berita yang bersertakan visual merupakan satu keperluan. ILN diedarkan dalam bentuk akhbar dan merupakan akhbar bervisual tertua dan pertama di England. ${ }^{23}$ ILN telah mengorak langkah untuk merakamkan visual peristiwa dalam laporannya. Antara berita yang sering dilaporkan terdiri daripada berita berkaitan dengan kerabat diraja, laporan peperangan yang berlaku di negara-negara jajahan British, sains dan kejuruteraan, komet, zoologi, selebriti atau teknologi terkini bagi tatapan umum di England. ${ }^{24} \mathrm{Di}$ antara para pengkarya yang menyumbang tenaga dan bakat mereka ialah Sir John Filbert, Henry Anely, Birket Foster, H. G. Hine dan Kenny Meadows. ${ }^{25}$ Malahan akhbar ini juga mendapat maklumat saintifik berupa sumbangan berita dan visual daripada saintis terkemuka iaitu Charles Piazzi Smyth, seorang ahli astronomi dari Scotland. Charles Piazzi Smyth sendiri merupakan pengkarya atau pencetak yang menghasilkan gurisan kayunya untuk dihantar ke bahagian seni akhbar tersebut. ${ }^{26}$ Namun begitu, sumbangan daripada pihak luar juga dialu-alukan oleh pihak penerbit ini. Umpamanya pada 1848, hasil kerja daripada pengkarya Perancis, Paul Gavarni merupakan penyumbang utama lakaran dan cetakan ketika berlakunya keadaan kacau bilau di Perancis. ${ }^{27}$

ILN merupakan terbitan yang mengandungi 16 halaman dan disertakan dengan 32 keping cetakan gurisan kayu sebagai visualnya pada peringkat awal penerbitan. ${ }^{28}$ ILN juga merupakan satu-satunya akhbar yang membuat laporan di seluruh dunia ketika era Victoria. Jumlah pengedarannya pada tahun 1863 mencapai 300,000 salinan berbanding akhbar harian terkemuka lain di England ketika itu yang hanya mampu menjual 70,000 salinan akhbar. ${ }^{29}$ ILN ialah akhbar sebenar yang telah mengangkat potensi cetakan gurisan kayu secara pesat dan produktif. Seni cetakan gurisan kayu membolehkan pihak editorial 
mencetak visual-visual berkaitan berita yang dihantar dalam kualiti yang amat baik dan saiz yang tidak pernah dihasilkan sebelum ini. ${ }^{30}$

Sesungguhnya kemajuan teknologi ketika itu juga memungkinkan proses ini berlaku, iaitu dengan kemajuan pengangkutan keretapi dan juga telegraf. Kedua-dua teknologi ini membolehkan berita dibawa balik ke ibu pejabat dengan cepat. ${ }^{31}$ Proses merakam visual selalunya dilakukan dalam bentuk lakaran asas iaitu sumbangan daripada pihak koresponden yang dilantik. Mereka sebenarnya merupakan kakitangan kerajaan antaranya yang bertugas sebagai pengkarya, jurutera, tentera, ahli sains dan orang perseorangan. Selepas lakaran itu tiba di pejabat akhbar, visual yang dihasilkan dalam bentuk yang lebih terperinci akan dilakarkan semula. Lukisan tersebut akhirnya akan dipindahkan di atas permukaan kayu 'Boxwood Turki' dalam bentuk terbalik, seterusnya meningkatkan imej dengan menggunakan dakwat India atau pensil agar memberikan imej akhir yang terbaik di atas gurisan kayu tersebut. 'Boxwood Turki' merupakan plat yang terbaik digunakan, tidak mempunyai serpihan dan berupaya untuk menghasilkan garisangarisan halus pada gurisan kayu tersebut. ${ }^{32}$ Dengan gabungan tenaga daripada asas sehinggalah ke cetakan akhir, semua itu membolehkan edaran akhbar bervisual ini sampai hingga ke tangan pembaca.

\section{Laporan Memburu Lanun}

Lanun merupakan ancaman kepada pedagang, pengembara serta penduduk pinggir laut. Keperluan untuk memburu lanun ialah suatu keutamaan yang diberikan oleh pihak British. Sepanjang sejarah, lanun laut telah menghalang dan menganiaya pedagang sehingga mengakibatkan krisis dan kerugian ekonomi. Mereka telah membunuh secara sengaja atau tidak sengaja pelayar dan penumpangnya yang tidak bersalah, menawan atau menjadikan hamba abdi serta menuntut tebusan selain diseksa dan dirogol. ${ }^{33}$ Oleh itu, dalam cetakan yang dikumpulkan ini akan berkisarkan tentang penghapusan lanun di Nusantara. Terdapat beberapa buah cetakan dengan jelas memberi gambaran operasi serangan itu kepada pembaca akhbar ILN. Penulisan ini akan berpandukan kepada susunan berikut, iaitu mengkaji cetakan gurisan kayu yang telah dihasilkan dan diterbitkan di ILN. Ia merangkumi aktiviti berkaitan lanun di Nusantara secara kronologi dari 1845-1872. Tindakan pihak British bagi membendung kegiatan lanun di Nusantara daripada laporan yang disediakan oleh ILN akan dihuraikan bagi memudahkan proses pengkajian visual dan menerangkan dalam konteks laporan berita berkaitan peristiwa. 


\section{Gambar 1: "The British Admiral's Attack on the Borneo Pirates" (Laksamana Angkatan Laut British Menyerang Lanun Borneo)}

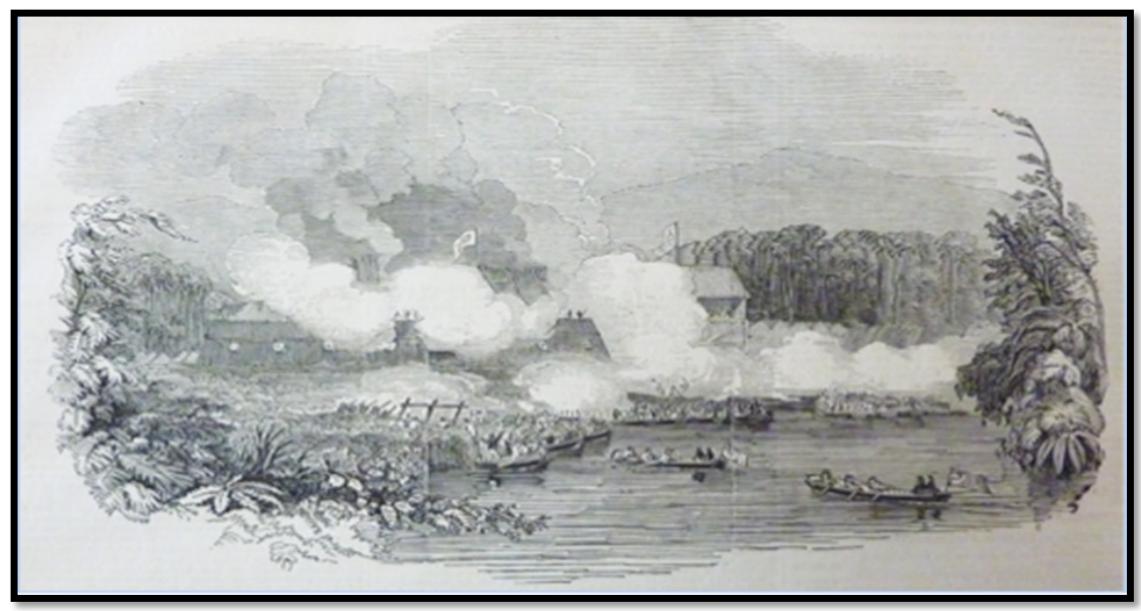

Sumber: The Illustrated London News, (November 29, 1845), National Art Library, Victoria \& Albert Museum, London.

Cetakan visual pertama bertajuk 'The British Admiral's Attack on the Borneo Pirates' (Laksamana Angkatan Laut British Menyerang Lanun Borneo) ini dihasilkan berdasarkan serangan tentera British terhadap kumpulan lanun di perairan kepulauan Borneo. Teknik cetakan yang digunakan ialah cetakan gurisan kayu. Cetakan yang diterbitkan pada 29 November 1845 ini dihasilkan oleh pengkarya daripada pasukan gurisan kayu ILN serta dicetak dalam warna hitam dan putih berukuran 23.6 centimeter $\times 15.7$ centimeter. Laporan peristiwa ini yang diterima daripada wartawan di Hong Kong merupakan sebuah cetakan yang terbahagi kepada tiga buah plat cetakan kayu. Cetakan ini merupakan visual yang dihantar oleh wakil akhbar yang berada di tempat kejadian untuk laporan serangan yang berlaku pada 10 Ogos di Sungai Marudu. Lakaran asal yang dihasilkan ketika peristiwa berlangsung merupakan hasil daripada seorang anggota tentera yang menyertai serangan tersebut secara peribadi. Setiap lakaran yang dihasilkan digambarkan sepertimana ianya berlaku dan laporan yang dibuat telah memperkukuhkan lagi penyataan visual tersebut. Cetakan ini bertujuan melaporkan serangan pihak British kepada sarang atau kubu pihak lanun di Borneo. Serangan ini diketuai oleh Kapal Perang 'Agincourt' dan turut disertai oleh beberapa buah kapal lagi iaitu, 'Vestal', 'Daedalus', 'Cruizer', 'Wolverine', 'Vixen', 'Nemesis', and 'Pluto' ${ }^{34}$ 
Visual ini jelas memperlihatkan tindakan pihak British menyerang sebuah kubu yang merupakan penempatan lanun. Kumpulan lanun yang dikatakan diketuai oleh Sahrif Osman berbangsa Arab ini merupakan kumpulan lanun yang telah melumpuhkan perdagangan di sekitar utara Borneo. ${ }^{35}$ Mereka dikatakan lanun yang kejam dan telah menyebabkan banyak kapal-kapal yang berlayar di perairan tersebut dilaporkan hilang. Kebanyakan kapal-kapal itu telah menerima nasib malang sekiranya ditawan, anak-anak kapalnya akan dibunuh atau dijual sebagai hamba. Di antara peristiwa serangan yang direkodkan adalah daripada laporan yang mengatakan terdapat satu kejadian menimpa 10 orang Eropah dan 30 orang lelaki lagi dari Manila. Mereka telah dijadikan hamba kepada ketua lanun yang kubunya telah dimusnahkan dalam peristiwa tersebut. Satu lagi peristiwa yang melibatkan dua orang berbangsa Sepanyol. Mereka telah dibawa ke Manila dan diperhambakan sementara rakan-rakan mereka dibunuh oleh lanun di Telok Marudu. ${ }^{36}$

Cetakan ini ialah visual Kapal Perang 'Agincourt' yang digunakan dengan kekuatan 500 orang serta 20 buah perahu yang diketuai oleh Sir. T. Cochrane sebagai 'Rear Admiral' dan 'Commander in Chief. . $^{37}$ Visual ini menjelaskan keadaan kekacauan yang sedang berlaku di kawasan serangan dan pertempuran. Perahu yang banyak menghampiri darat serta asap yang berkepul-kepul mengelilingi kawasan kubu lanun tersebut. Pasukan bersenjata telah berjaya mengukuhkan kedudukan di sekitar kawasan luar kubu. Dilaporkan terdapat empat jenis buah meriam di pihak lawan iaitu empat buah meriam 15 pound, dua buah meriam 12 pound, tiga buah meriam Sembilan pound dan dua buah meriam enam pound. ${ }^{38}$ Sementara di pihak British pula telah membawa senjata sebanyak 30 buah dan lapan buah senjata pada bot-bot mereka. ${ }^{39}$ Kubu tersebut akhirnya berjaya dimusnahkan akibat kebakaran daripada serangan dan arahan yang diberikan. Dengan kejayaan membunuh lima daripada 10 orang ketua angkatan lanun tersebut, pihak British telah berjaya mematahkan kekuatan lanun seramai 1000 orang ketika itu. ${ }^{40}$ Sebaliknya di pihak British pula seramai enam orang anggota tentera telah terbunuh, 15 lagi tercedera dan dua daripadanya cedera parah. ${ }^{41}$

Melalui peristiwa itu maka cetakan ini dihasilkan untuk satu tujuan iaitu melaporkan serangan pihak British terhadap sarang atau kubu pihak lanun di Borneo. Visual ini juga digunakan bagi memperlihatkan bagaimana pihak musuh menghadapi keadaan sukar berhadapan dengan serangan dari pihak British. Serangan yang diketuai oleh Kapal Perang Agincourt dan turut disertai oleh beberapa buah kapal lain ini juga telah memyebabkan ketua lanun serta kuncu-kuncunya dapat ditewas dan diberkas. 


\section{Gambar 2: "View In The New Colony of Labuan" (Pemandangan Wilayah baru Labuan)}

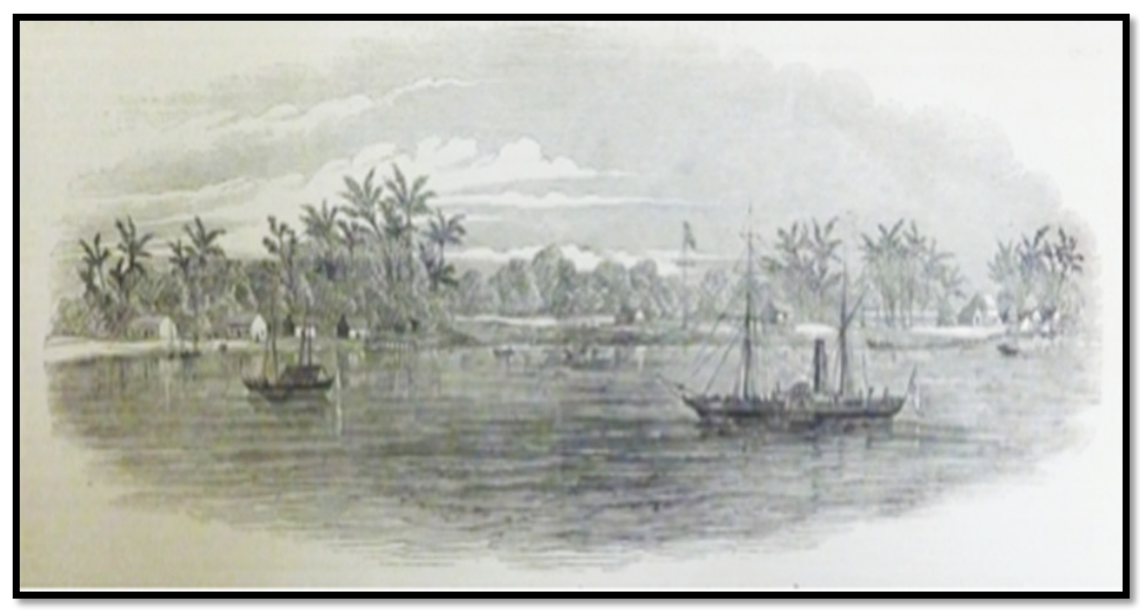

Sumber: The Illustrated London News, (December 9, 1848), National Art Library, Victoria \& Albert Museum, London.

Visual pemandangan di Labuan ini dilukis oleh Dr. Startinyang bertugas sebagai Pegawai Perubatan Syarikat India Timur, Kapal Wap 'Phlegethon'. ${ }^{42}$ Cetakan ini dicetak dan diterbitkan oleh pihak akhbar ILN. ${ }^{43}$ Pasukan gurisan kayu ILN telah menghasilkan cetakan semula lakaran ini bagi mengiringi laporan yang dibuat. Cetakan tersebut bersaiz $23.6 \times 8.9 \mathrm{~cm}$, berwarna hitam dan putih. Cetakan yang dihasilkan dengan menggunakan dua plat cetakan memberi gambaran jelas pemandangan Pulau Labuan ketika itu. Pulau ini juga pernah dikenali sebagai pulau Victoria oleh pihak British. ${ }^{44}$ Visual ini mengambarkan pelabuhan di Labuan, salah sebuah pelabuhan milik British yang diperolehi daripada Kerajaan Brunei pada 18 Disember 1846. ${ }^{45}$ Pulau Labuan yang bersaiz 35 batu persegi berkedudukan di Laut China Selatan di kepulauan Borneo diperoleh oleh pihak British sebagai pengkalan untuk membenteras serangan lanun di Borneo. ${ }^{46}$

Penerangan yang diberikan oleh pihak akhbar berkaitan visual ini merujuk kepada tempat letak bangunan-bangunan yang terdapat di sekitar pelabuhan itu. Bangunan tersebut terdiri daripada banglo kerajaan dan rumah pengawal di sebelah kanan gambar. Ia dituruti pejara dengan perumah tentera laut. Kelihatan juga di bahagian hadapan visual ini ialah Kapal Enjin Wap 'Phlegethon'. ${ }^{47}$ Walaupun dalam karya ini tidak ada aktiviti menyerang lanun namun kepentingannya dalam agenda British memerangi lanun di Borneo amat penting. 
Cetakan ini juga merupakan visual untuk memperkenalkan kapal perang enjin wap 'Phlegerhon' kepada umum. Kapal ini telah diberi arahan dalam usaha untuk memburu lanun di perairan Nusantara. Tujuan kapal ini berlayar di perairan tersebut adalah untuk menangkap para lanun yang telah memusnahkan serta membunuh anak kapal dan penumpang sebuah kapal bernama 'General Wood' setahun sebelum itu. ${ }^{48}$ Operasi tersebut telah menemui kejayaan apabila 30 orang lanun telah ditawan dan dibawa ke Singapura. ${ }^{49}$ Visual ini menunjukan dari jauh kapal tersebut yang dilengkapi dengan bendera di buritan kapal serta 'pedel' enjin wap serta serombong yang membezakannya dengan kapal layar biasa yang diguna pakai ketika era itu. Tidak ketinggalan kapal layar ini turut dilengkapi dengan dua tiang layar.

Kepantasan kapal laut lanun di Nusantara sentiasa ditulis oleh para pelayar dan pedagang. Cetakan ini telah divisualkan oleh Pasukan Gurisan Kayu, ILN. Lakaran dihasilkan oleh Kapten W. Thornton Bate ${ }^{50}$ mengenai kejadian kejar-mengejar di antara pelayar lanun dengan anakanak kapal H.N.S 'Royalis' ketika kedudukan perahu kira-kira 9 batu dari kapal induk. ${ }^{51}$ Karya ini tetap menggunakan teknik gurisan kayu, warna hitam putih serta bersaiz 23.6 x $10.8 \mathrm{~cm}$. Kejadian dilaporkan yang berlaku di Selat 'Endeavour' iaitu selat yang berkedudukan di antara Borneo Utara dan Pulau Palawan.

\section{Gambar 3: "Fleet of Malay Pirates and "Royalist" boat in Endeavour Straits".}

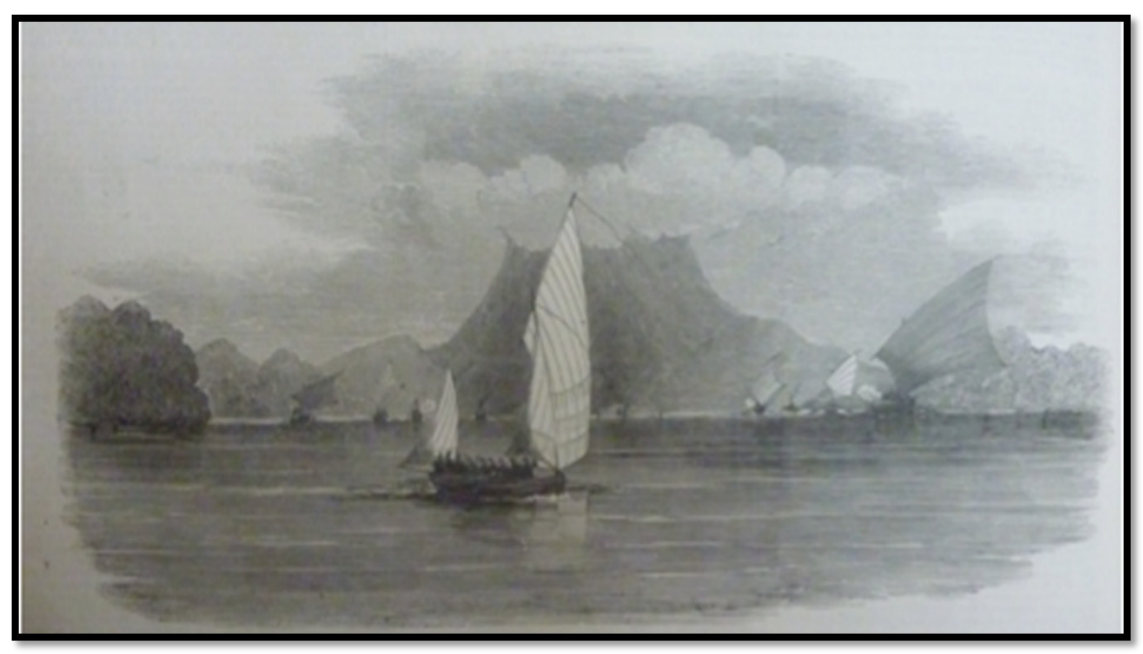

Sumber: The Illustrated London News, April 24, 1852, National Art Library, Victoria \& Albert Museum, London. 
Keselamatan dan kepentingan pihak British di Nusantara telah memerlukan tugasan pemantauan dijalankan. Di antara kapal yang ditugaskan ialah Kapal 'Royalist'. Kapal ini telah menjalankan tugas dalam memastikan kawasan di sekitar kepentingan pihak British sentiasa selamat daripada ancaman lanun. Tugasan ini telah diserahkan kepada Kapten Bate oleh Sir F. Beaufort untuk menjalankan pemantauan di sekitar perairan China. ${ }^{52}$ Visual ini berdasarkan daripada laporan rasmi yang dibuat oleh Komander Bate. Laporan tersebut menyatakan satu peristiwa yang berlaku ketika ia ditugaskan untuk memantau dan membuat tinjauan terhadap Pulau Palawan (Filipina) yang terletak di antara Laut Cina Selatan dan Laut Sulu. ${ }^{53}$ Dalam usaha untuk merekod dan membuat laporan di pulau tersebut pihak British telah meninggalkan kapal induk dan mendayung perahu ke daratan. Kali ini tugasan mereka adalah untuk menghasilkan laporan lengkap tipografi dan lain-lain yang berkaitan dengan muka bumi. Ketika di Pancol, sebuah pulau yang menjadi sebahagian dari tanah jajahan Sepanyol, mereka telah mendapat maklumat dari penduduk asal yang menyatakan terdapat tujuh buah kapal lanun berdekatan. ${ }^{54}$ Adalah difahamkan bahawa lanun Melayu mempunyai armada dalam bentuk perahu panjang dan perahu perang yang masing-masing berukuran kira-kira sembilan puluh kaki atau lebih panjang. Selain membawa senjata tembaga, lanun ini juga bersenjatakan pedang dan lembing serta senapang. Setiap sampan selalunya akan dikayuh oleh $60-80$ orang lelaki. ${ }^{55}$ Walaupun serangan ini tidak berjaya namun ia merupakan satu serangan yang penting dan secara tidak langsung kekuatan pihak lanun dapat dikaji.

Cetakan ini telah memperlihatkan bagaimana sebuah perahu milik British dikejar dan ditembak oleh pihak lanun. Dalam visual ini kelihatan sebuah perahu dari kapal 'Royalist' yang sedang berlayar dengan tenaga dayungan dan layar berlatarbelakang beberapa buah kapal Lanun Melayu. Lanun Melayu yang berada di kepulauan tersebut telah keluar di sebalik pulau tempat persembunyian mereka untuk menawan perahu tersebut. Serangan itu disusuli dengan tembakan yang dilepaskan daripada meriam yang diberi nama 'Lelah' ${ }^{56}$ Perahu lanun ketika itu direkodkan sebanyak lapan buah dan anggaran anak kapal berjumlah 400 orang. Lima buah perahu besar bersedia untuk menyerang jelas kelihatan. ${ }^{57}$ Ia merupakan adegan kejar mengejar yang berlatarbelakangkan gunung 'Malampaya Table. ${ }^{58}$ Usaha lanun tersebut telah gagal dan pihak British telah berjaya mengelak dan melepaskan diri daripada serangan tersebut.

"The Expedition Crossing the Bar of the River at Tunku" (Ekspedisi menyeberang benteng sungai di Kampung Tunku), bersaiz 11.4 x $8.2 \mathrm{~cm}$ dicetak dalam hitam putih oleh pasukan gurisan kayu ILN. Ia merupakan sebuah karya yang berlatarkan muara sungai di 
Telok Meludu, di mana beberapa buah perahu kelihatan memasuki muara sungai dari lautan terbuka. Di antara muara sungai dan lautan kelihatan ramai anggota tentera dalam keadaan melakukan aktiviti menarik perahu yang terkandas. Di garisan horizon di sebelah kanan kelihatan tiga buah kapal yang sudah berlabuh dan setiap kapal itu telah diturunkan layarnya. Kapal-kapal tersebut merupakan kapal H.M.S 'Cleopatra' yang diketuai oleh Kapten Massie, 'Semiramis' diketuai oleh Komanden Stephens dan Kapal 'Pluto' . ${ }^{9}$

Gambar 4: "The Expedition Crossing the Bar of the River at Tunku." (Ekspedisi menyeberang benteng sungai di Kampung Tunku)

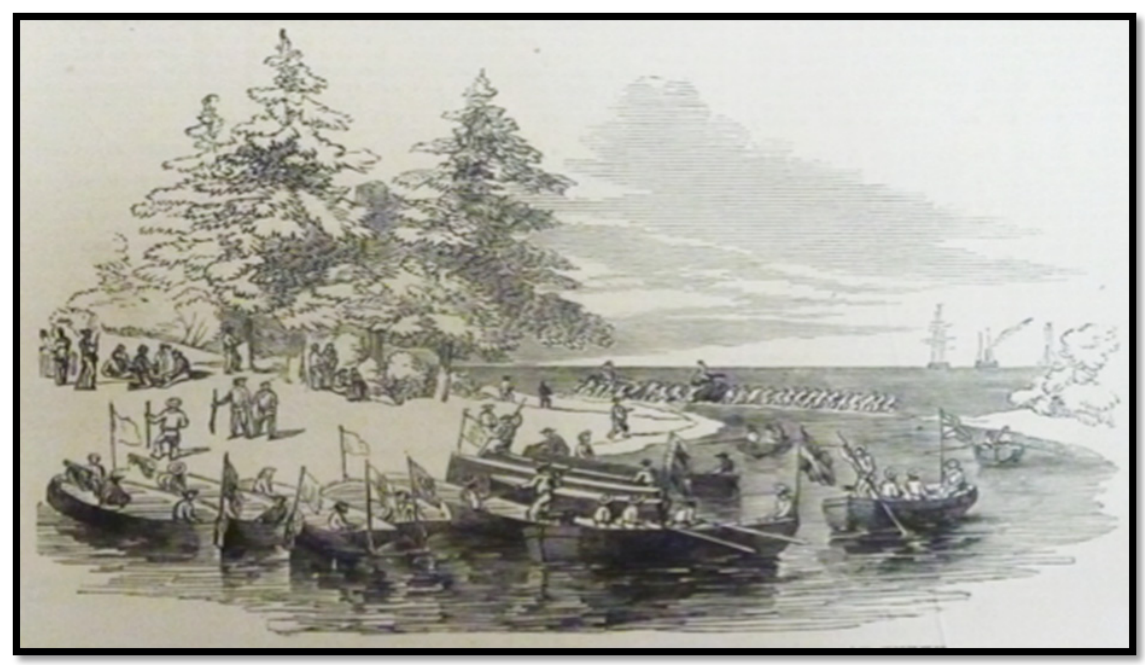

Sumber: The Illustrated London News, (29 Mei, 1952), National Art Library, Victoria \& Albert Museum, London.

Cetakan ini adalah berdasarkan laporan tindakan British terhadap lanun di Borneo berikutan peristiwa lanun yang menyerang pedagang dari kapal 'Dolphin' pada 13 September 1851. Serangan itu telah menyebabkan kematian Kapten, seorang penumpang serta lima orang anak kapal. ${ }^{60}$ Pada 15 Fabruari 1852, British telah mendarat di Telok Maladu dan cetakan ini kelihatan setibanya dan ketiga-tiga kapal tersebut berlabuh. ${ }^{61}$ Oleh kerana keadaan alam semulajadi yang tidak sesuai untuk kapal-kapal tersebut menghampiri penempatan lanun, mereka telah menghantar beberapa buah perahu masuk ke muara sungai. Setiap perahu dipenuhi dengan tentera. Cetakan ini memperlihatkan 14 buah perahu termasuk perahu yang terkandas. 
Meenurut rekod, terdapat 15 buah perahu serta 250 orang tentera yang mendarat di sana dan setiap perahu telah dipasang dengan bendera putih. ${ }^{62}$

Cetakan yang divisualkan ini bertujuan merakamkan peristiwa halangan benteng pasir yang dihadapi oleh bala tentera untuk ke kubu lanun di Kampung Tungku. Kelihatan usaha untuk membawa masuk perahu yang lengkap dengan meriam dan senjata berat. Keadaan air laut pasang surut telah menyukarkan usaha tersebut. Keadaan ini telah memaksa pihak tentera untuk menarik keluar perahu tersebut dengan kerahan tenaga.

\section{Gambar 5: “The Attack” (Serangan)}

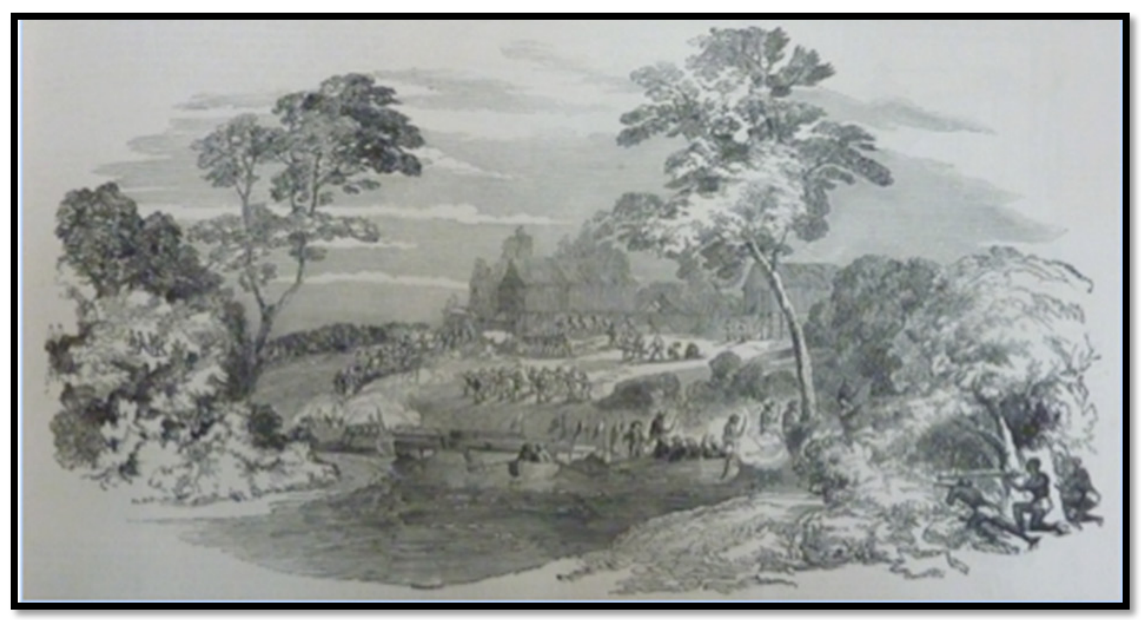

Sumber: The Illustrated London News, (29 Mei, 1852), National Art Library, Victoria \& Albert Museum, London, hlm. 423.

"The Attack" (Serangan) laporan visual yang dihasilkan oleh anggota tentera yang terlibat dalam peristiwa tersebut telah dihantar ke ibu pejabat akhbar ILN bertarikh 16 Mac 1852. ${ }^{63}$ Pasukan Gurisan Kayu, ILN telah menghasilkan visual cetakan gurisan kayu berwarna hitam putih saiz 23.6 x $13.2 \mathrm{~cm}$. Sebuah cetakan yang mempunyai pelbagai aktiviti serangan yang berbeza daripada karya cetakan yang lain. Cetakan sebelum ini hanya memperlihatkan perjuangan daripada sebelah pihak sahaja namun pada karya ini penglibatan orang tempatan dan bala tentera yang menyerang turut dirakamkan.

Peristiwa ini berpunca daripada serangan lanun terhadap sebuah kapal dagang 'Dolphin'. Kapal tersebut telah ditawan dan dibawa lari oleh pihak lanun ke Telok Labok. Kemudiannya kapal tersebut ditemui semula oleh Penghulu Shereef Yassin yang berasal dari Kampung 
Tungku dan kemudiannya menawan semula kapal tersebut dari pihak lanun. Setelah berjaya menawannya, kapal tersebut dihantar kepada pihak British melalui kapal perang 'Pluto' yang sedang menjalankan usaha mencari kapal tersebut. Namun pihak British mencurigai beliau yang mungkin turut terlibat sama dalam hal tersebut. Untuk mendapatkan maklumat lebih lanjut berkaitan peristiwa tersebut, pihak British telah menghantar sebuah Kapal Perang H.M.S. 'Cleopatra' ke Borneo pada 10 Januari $1852 .{ }^{64}$ Kapal ini kemudiannya bergabung dengan dua buah lagi kapal perang yang telah dihantar terlebih dahulu bagi tugasan tersebut iaitu, 'Semiramis' dan 'Pluto' untuk memberi bantuan dalam proses tersebut.

Cetakan ini berjaya memberi penjelasan dan gambaran yang diperlukan oleh pelbagai pihak. Misalnya kekuatan tentera, penentangan dari pihak lawan atau tempatan, kawasan penempatan yang ditinggalkan dan penduduk yang melarikan diri dapat diperjelaskan dengan terperinci. Dalam laporan dinyatakan penempatan ini telah ditinggalkan tetapi melalui tinggalan unggun api yang masih terdapat di sana jelas menunjukan ianya baru sahaja berlaku. ${ }^{65}$ Walaupun telah dikosongkan tetapi masih terdapat beberapa serangan penentangan daripada beberapa orang tempatan (disyaki lanun). Cetakan ini menunjukan beberapa orang tempatan membedil musuh dengan menggunakan sebuah meriam kecil. ${ }^{66}$ Manakala seorang lagi bersembunyi di sebalik pokok dan semak samun di hadapannya. Rimbunan pokok-pokok tersebut telah menjadi pembahagi di antara sekumpulan anggota tentera yang berperahu mendarat dengan senjata pedang di tangan. Akibat daripada beberapa siri serangan hendap, pihak British telah kehilangan seorang anggota tentera dan dua orang lagi tercedera ketika serangan pertama. ${ }^{67}$ Ketika serangan kedua pula, dua anggota tentera tercedera dan seorang lagi terbunuh. Anggota tentera yang terbunuh disebabkan senjata beliau meletup dengan sendirinya sehingga menyebabkan peluru tersebut menembusi kepalanya. Berikutan daripada peristiwa serang hendap tersebut pihak British telah diletakkan dalam kedudukan berjaga-jaga.

Satu lagi cetakan berkesinambungan daripada peristiwa di Kampung 'Tengku' ialah karya "The Funeral At Sea” (Pengebumian di Lautan) yang merupakan gurisan kayu hitam putih bersaiz 11.4 x 8.2 $\mathrm{cm}$. Peristiwa yang berlaku pada 19 Fabruari 1852 ini dirakamkan dalam lembaran ILN, berkisar acara pengebumian anggota tentera British. ${ }^{68}$ Daripada cetakan ini kelihatan lima buah perahu di tengah-tengah karya yang dipenuhi dengan ramai pendayung setiap satu. Disiplin dalam majlis pengebumian ketenteraan jelas diperlihatkan iaitu anggota yang mengiringi jenazah melakukan aktiviti-aktiviti menghormati si mati. Mayat askar yang terkorban diletakkan di bahagian tengah, setiap satu 
menampakkan bungkusan mayat yang sedang dalam gerakan untuk dilepaskan ke laut dalam. Beberapa figura yang sedang memegang dua buah beg empat segi dalam keadaan membongkok. Peristiwa tersebut merupakan pengebumian anggota tentera yang terkorban ketika dua serangan hendap di Kampung Tungku sebelum ini.

\section{Gambar 6: "The Funeral At Sea" (Pengebumian di Lautan)}

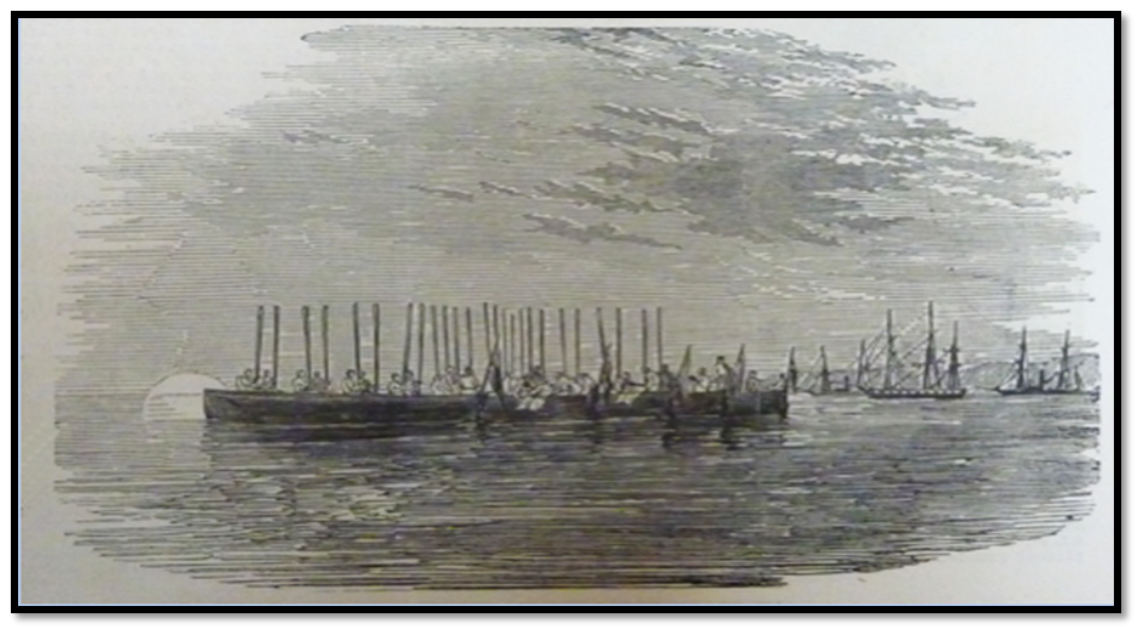

Sumber: The Illustrated London News, (29 Mei, 1852), National Art Library, Victoria \& Albert Museum, London.

Selain itu, kelihatan seorang daripada mereka sedang membaca kitab serta seorang yang sedang berdiri di sebelahnya iaitu di tangan kirinya memegang bendera dan di sebelah tangan kanannya memegang topi. Setiap perahu terdapat bendera di hujung sampan dan para pendayung mengangkat dayung mereka dalam keadaan menegak. Di sebelah kanan kelihatan tiga buah kapal yang menyertai operasi tersebut sedang berlabuh dengan layarnya tidak dipasang dan berlatarkan dataran tanah tinggi. Cetakan ini telah berjaya mengambarkan keadaan ketika itu yang dipenuhi dengan kesayuan dan kesedihan kerana beberapa anggota tentera telah terkorban semasa operasi menghapuskan lanun di Utara Borneo. Aktiviti ini dilakukan selepas operasi selesai dan pihak British dalam perjalanan kembali ke Labuan. Mereka tiba di Labuan pada 28 Fabruari 1852 untuk mendapatkan bekalan arang batu bagi kegunaan kapal wap tersebut. ${ }^{69}$

Di samping itu, terdapat juga visual peristiwa serangan ke atas penempatan lanun pada karya berjudul “Destruction Of A Pirates' 
Stronghold By H.M.S. Nassau" (Pemusnahan kubu kuat lanun oleh angkatan HMS Nassau). Berita dicetak bertarikh 5 Oktober 1872 di ILN dalam cetakan hitam dan putih bersaiz 23.6 x $13.8 \mathrm{~cm}$ dengan teknik gurisan kayu oleh pasukan gurisan kayu. Lakaran peristiwa dihasilkan oleh salah seorang pegawai yang menyertai serangan tersebut. Cetakan ini merupakan satu lagi visual yang ditunjukkan dengan jelas kawasan serangan ke atas Lanun di Nusantara, terutama di Sulu.

\section{Gambar 7: "Destruction of A Pirates' Stronghold By H.M.S. Nassau" (Pemusnahan Kubu kuat Lanun oleh angkatan HMS Nassau)}

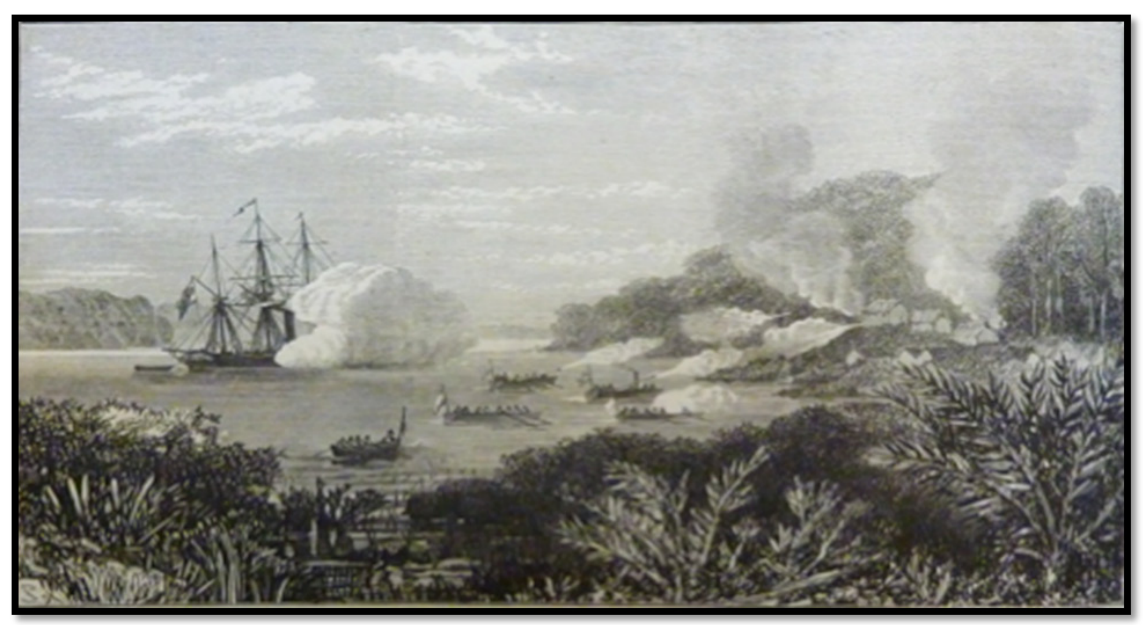

Sumber: The Illustrated London News, (5 Oktober, 1872), National Art Library, Victoria \& Albert Museum, London, hlm. 423.

Cetakan ini memperlihatkan serangan yang dibuat dengan menggunakan Kapal Perang H.M.S. 'Nassau' yang diketuai oleh Komander R.N.William Chimmo. ${ }^{70}$ Menurut laporan, kumpulan lanun ini merupakan kumpulan yang telah menyerang anak kapal dari kapal H.M.S 'Nassau'. Mereka ditugaskan untuk membuat tinjauan bagi tujuan membina Pelabuhan Dalrymple di Pulau Sulu. ${ }^{71}$ Serangan hendap daripada pihak lanun itu menyebabkan beberapa orang pegawai dan anak kapal cedera parah dan terbunuh. Serangan dilakukan pada 11 Mei 1872 kira-kira pukul 5.30 pagi. $^{72}$ Kejadian berlaku di Carangcarang, iaitu merupakan kubu kuat pihak lanun di Sulu. ${ }^{73}$

Visual ini memperlihatkan dengan jelas kapal perang dan perahu lengkap bersenjata telah menyerang ke arah darat kedudukan kubu dan perkampungan lanun. Kelihatan asap daripada muncung meriam 
yang terhunus di dua buah perahu manakala sebuah lagi tidak kelihatan meriamnya sepertimana kelihatan dari arah kapal perang tersebut. Begitu juga peluru meriam menghala ke rumah-rumah yang terletak di atas daratan di tebing sungai dan kelihatan seperti roket berekor asap. Cetakan ini memperlihatkan rakaman posisi kapal perang, perahu dan juga penempatan lanun yang diserang. Serangan ini bertujuan menghancurkan penempatan tersebut. Setelah berjaya dimusnahkan dan dibakar oleh pihak British, tindakan tersebut kemudiannya dimaklumkan kepada Sultan Sulu dan baginda menerima dan memperkenankan tindakan yang dijalankan itu. ${ }^{74}$

\section{Kesimpulan}

Kesimpulannya, tujuh buah karya yang dicetak pada akhbar The Illustrated London News ini menunjukkan cara penyampaian berita kepada umum melalui cetakan gurisan kayu. Cetakan gurisan kayu ini memberi gambaran dari sudut visual berkaitan peristiwa yang berlaku ketika itu. Para pegawai tentera yang sememangnya berada di tempat kejadian telah memberi lakaran kejadian bagi mengiringi laporan berbentuk teks untuk tujuan penerbitan. Akhbar ini telah berjaya menyampaikan maklumat bukan sahaja berbentuk teks malahan visual bagi setiap operasi yang telah dijalankan.

Ancaman lanun membantutkan perkembangan perniagaan pihak British dan memaksa mereka melakukan serangan balas. Bukan sahaja keselamatan pedagang, malahan keselamatan pengembara dan pelancong juga diambil berat dalam isu ini. Proses menghapuskan lanun iaitu dengan mengepung pihak lanun di hulu memusnahkan kapal, rumah-rumah mereka, kubu pertahanan dan menangkap atau membunuh terus lanun tersebut dijalankan secara sistematik. Strategi ini membuahkan hasil dan berjaya menghapuskan lanunlanun dan pengikutnya. Hal yang demikian berjaya memperlihatkan kepada umum tentang keupayaan tentera British dalam usaha untuk memerangi dan menghapuskan lanun di Nusantara, terutama sekali di Borneo Utara. Rekod yang dilakukan oleh Raja Brooke, dalam menangani masalah lanun yang berlaku dapat diperjelaskan secara visual apabila disebutkan bahawa strategi mengepung, memusnah dan menghapuskan telah dijalankan oleh pihak British terhadap sarangsarang atau kubu-kubu lanun yang ditawan oleh mereka. 


\section{Nota}

1 Benerson Little, Pirate Hunting: The Fight against Pirates, Privateers, and Sea Raiders from Antiquity to the Present, Virginia: Potomac Books Incorporated, 2010, hlm. 36.

2 Dewan Bahasa \& Pustaka, Lanun, http://prpm.dbp.gov.my/Search. aspx?k=lanun (tarikh diakses 27 Mei 2013).

3 Benerson Little, Pirate Hunting, hlm. 5.

4 Donald B. Freeman, Straits of Malacca: Gateway or Gauntlet?, Montreal: McGill-Queen's University Press, 2003, hlm. 175.

$5 \quad$ Ibid., hlm. 176.

6 Simon Richmond, Malaysia, Singapore \& Brunei 11, London: Lonely Planet, 2010, hlm. 148.

7 Rachel Hanel, Pirates, Minnesota: Creative Education, 2007, hlm. 8.

8 Benerson Little, Pirate Hunting, hlm. 36

9 Ibid.

10 Ada Pryer, A Decade in Borneo, London: A Continuum imprint, 2001, hlm. 2.

11 Ibid.

12 Nicholas Tarling, The Cambridge History of Southeast Asia: From Early Times to C. 1800, Vol. 1, Cambridge: Cambridge University Press, 1992, hlm. 19 $\& 20$.

Gordon L. Rottman, World War 2 Pacific Island Guide, Westpost: Greenwood Publishing Group, 2002, hlm. 205.

Chris Rowthorn \& Muhammad Cohen, Borneo, Melbourne: Lonely Planet, 2008, hlm. 23. Jerry Dupont, The Common Law Abroad: Constitutional and Legal Legacy of the British Empire, New York: William S. Hein \& Co., 2001, hlm. 663. Gordon L. Rottman, World War 2 Pacific Island Guide, hlm. 205. Ibid.

Laurel Brake \& Marysa Demoor, Dictionary of Nineteenth-Century Journalism in Great Britain and Ireland, London: Academia Press Scientific Pub, 2009, hlm. 302. Rujuk juga Douglas W. Bostick, The Confederacy's Secret Weapon: The Civil War Illustrations of Frank Vizetelly, Charleston: The History Press, 2009, hlm. 11.

19 Laurel Brake \& Marysa Demoor, Dictionary of Nineteenth-Century Journalism in Great Britain and Ireland, hlm. 302.

20 Peter E. Palmquist \& Thomas R. Kailbourn, Pioneer Photographers of the Far West: A Biographical Dictionary, 1840-1865, Stanford: Stanford University Press, 2000, hlm. 319.

21 Douglas W. Bostick, The Confederacy's Secret Weapon: The Civil War Illustrations of Frank Vizetelly, Charleston: The History Press, 2009, hlm. 11. Jane L. Chapman and Nick Nuttall, Journalism Today: A Themed History, New Jersey: Wiley-Blackwell, 2011, hlm. 319.

23 Douglas W. Bostick, The Confederacy's Secret Weapon, hlm. 11. 
James A. Secord, Victorian Sensation: The Extraordinary Publication, Reception, and Secret Authorship of Vestiges of the Natural History of Creation, Chicago: University of Chicago Press, 2001, hlm. 448.

Laurel Brake \& Marysa Demoor, Dictionary of Nineteenth-Century Journalism in Great Britain and Ireland, hlm. 302.

Jennifer G. Tucker, Nature Exposed: Photography as Eyewitness in Victorian Science, Baltimore: Johns Hopkins University Press, 2006, hlm. 111.

Ibid.

Douglas W. Bostick, The Confederacy's Secret Weapon, hlm. 11.

Ibid.

James A. Secord, Victorian Sensation, hlm. 448.

Ibid.

Douglas W. Bostick, The Confederacy's Secret Weapon, hlm. 12.

Benerson Little, Pirate Hunting, hlm 11-12.

Nautical Magazine, January 1846.

William L. Clowes \& Clements R. Markham, The Royal Navy: A History from the Earliest Times to the Present, Vol. 1, London: Naval Institute Press, 1897, hlm. 329.

The Illustrated London News, 29 November 1845.

Ibid.

Ibid.

Ibid.

Ibid.

William L. Clowes, et. al., The Royal Navy, hlm. 331.

Elijah C. Bridgman \& Samuel W. Willaims, The Chinese Repository, Vol. 3, Canton: The Proprietors, 1835, hlm. 269.

The Illustrated London News, 9 Disember 1848.

Stephen R. Evans et. al., The History of Labuan Island (Victoria Island), Paya Lebar: Calender Print Pte. Ltd., 1996, hlm. v.

Arthur Mills, Colonial Constitutions: an Outline of the Constitutional History and Exizting Government of The British Dependencies, London: Woodfall and Kinder, 1856, hlm. 148.

James Stuart Olson \& Robert Shadle, Historical Dictionary of the British Empire: K-Z, Connecticut: Grewood Publishing Group Inc., 1996, hlm. 645.

The Illustrated London News, 9 Disember 1848.

Ibid.

Ibid.

Kapten W. Thornton Bate dilahirkan pada 1820. Menyertai Royal Navel College, Portsmouth ketika berumur 13 tahun. Tugasan pertama adalah di atas kapal HMS Isis dan belajar ke Tanjung Harapan, Afrika Selatan. Kemudian bertugas di Kapal HMS Britannia sehingga menjawat jawatan sebagai leftenant. Beliau kemudiannya ditugaskan untuk HMS Blenheim yang membawanya ke China dan terlibat dalam peperangan Candu Petama yang meletus di sana. Pada 1846 beliau kembali ke England dan menghadiri kursus di Woolwich Colage, Portsmouth. Beliau dinaikkan pangkat pada 1848 dan diberi tugasan pemerintah kapal HMS Royalist sebagai Komander. Tugasan itu telah membawa beliau dalam menjalankan 
kajiselidik di Pulau Palawan. John Baillie \& William T. Bate, A Memoir of Captain W. Thornton Bate Rn, New York: Robert Carter \& Brothers, 1859, hlm. 1.

$51 \quad$ The Illustrated London News, 24 April 1852.

52 John Baillie \& William T. Bate, A Memoir of Captain W. Thornton Bate Rn, hlm. 47.

$53 \quad$ The Illustrated London News, 24 April 1852.

54 Ibid.

55 Benerson Little, Pirate Hunting, hlm 11-12.

56 Ibid.

$57 \quad$ The Illustrated London News, 24 April 1852.

$58 \quad$ The Illustrated London News, 24 April 1852.

59 Charles R. Low, The History of the Indian Navy (1613-1863), Cambridge: Cambridge University Press, 2012, hlm. 292.

60 The Illustrated London News, 29 Mei 1852.

61 Charles R. Low, The History of the Indian Navy, hlm. 293.

62 Ibid.

63 Ibid., hlm. 292.

64 Ibid.

65 The Illustrated London News, 29 Mei, 1852.

66 Ibid.

67 Charles Rathbone Low, The History of the Indian Navy, hlm. 293.

68 Ibid., hlm. 294.

69 Ibid., hlm. 204.

70 Nautical Magazine and Journal of the Naval Reserve, No. 40, 1871.

71 The Illustrated London News, 5 Oktober, 1872.

72 Ibid.

73 Ibid.

74 The Illustrated London News, 5 Oktober, 1872. 